\title{
Prediction of power demand for ship motion control system of sea mining ship fitted with tubular winning system
}

\author{
Monika Bortnowska, \\ Szczecin University of Technology
}

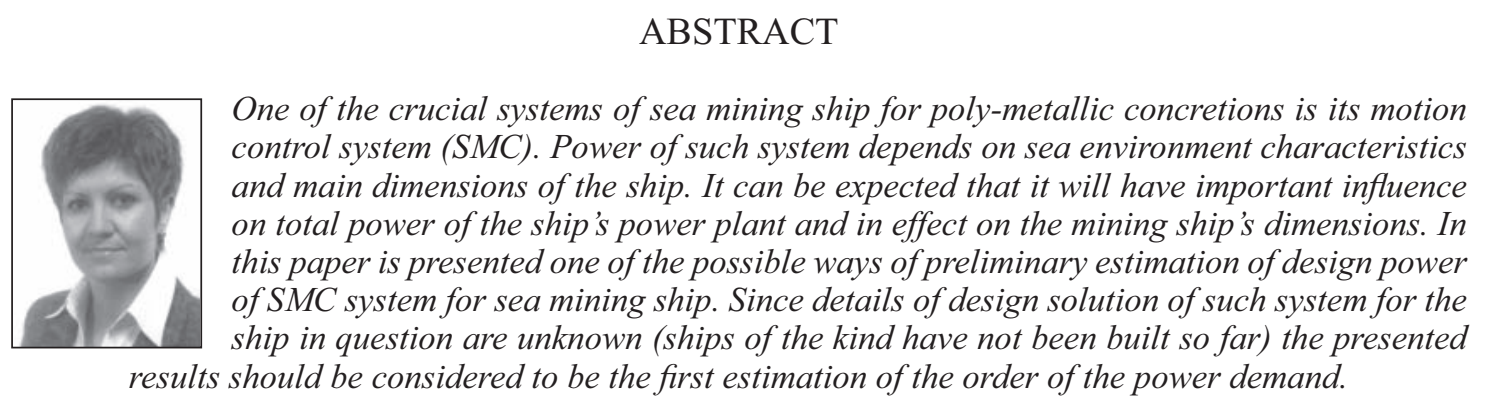

Keywords: sea mining ship, tubular winning system, action of sea environment, thrust of ship propellers, power of ship motion control system.

\section{INTRODUCTION}

Mining process of poly-metallic concretions from seabed is assumed to be carried out by using three basic elements: a bottom gathering vehicle, tubular winning system (called further also TW system) and floating winning unit.

One of the concepts of the mining facility for the concretions - most often taken into consideration - is that composed of a conventional single-hull ship providing possible storing the concretions in its holds, equipped with a vertical tubular winning system and self-propelled gathering device.

The mining ship makes correct functioning both the bottom gathering vehicle and tubular winning system, possible (by supporting them and delivering electric power).

During the mining process the vehicle moving over seabed will gather the concretions and pass on them to the TW hydraulic system. The mining ship to which the pipe of the TW system is hung, will have to monitor the gathering vehicle's motions, moving with a steady speed and keeping course within a corridor of a given width (Fig. 1).

Like other ocean engineering floating units the mining ship, to fulfill its functions often in heavy environmental conditions is to be fitted with an appropriate system for its motion control. The system has to ensure not only keeping the ship's position and course by means of special propellers [e.g. azimuthing ones like in the case of dynamic positioning systems (DSP)] but also to make continuous and precise moving the mining ship along a given trajectory possible, coping with unfavourable action of sea environment (wind, sea current, waves), resistance to motion of the ship and tubular winning system.

Such mining ship's motion control system (called further shortly SMC system) is crucial because of :

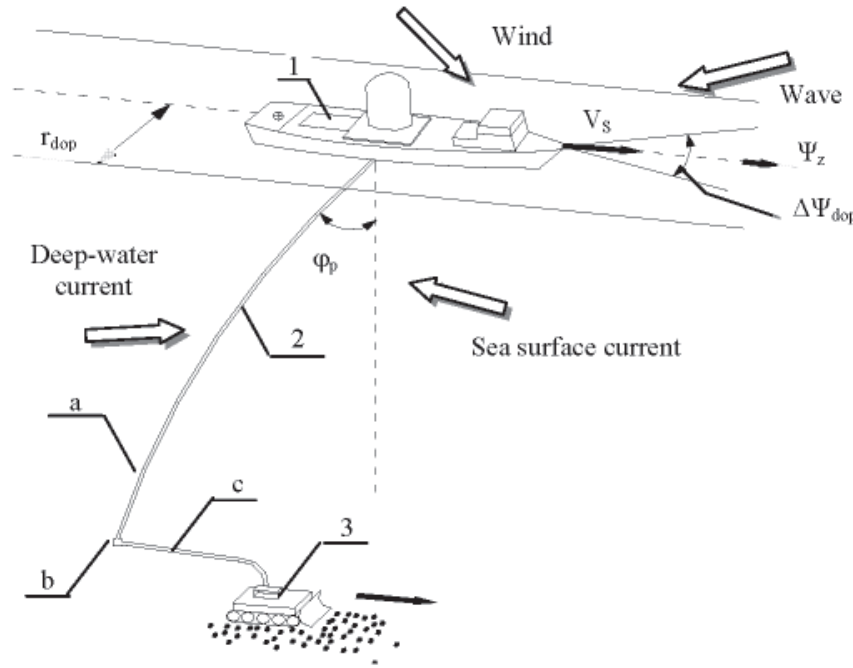

Fig.1. Motion control of mining ship moving along a given trajectory within a corridor.

Notation : $\mathbf{1}$-mining ship, $\mathbf{2}$ - tubular winning system: $\boldsymbol{a}$-vertical pipe, $\boldsymbol{b}$ - buffer, $\boldsymbol{c}$ - horizontal elastic pipe of zero-buoyancy (for the compensating of buffer's position changes against the gathering vehicle), 3 -bottom gathering vehicle (negligible influence of the mining ship - winning device system is assumed due to compensating action of horizontal elastic pipe between the buffer and gathering vehicle) $V_{s}$-ship speed

$\Rightarrow$ realization of main functions of the ship moving over deep-water areas

$\Rightarrow$ large power demand (the motion control system's power is expected to be large as compared with that of the whole electric power plant)

$\Rightarrow$ investment and service costs of the ship 
$\Rightarrow$ volumetric subdivision and design parameters of the ship: displacement, deadweight etc.

Value of the power delivered to propellers should be such as to obtain resultant thrust value sufficient to balance (without using redundant propellers) resultant action of sea environment in the most unfavourable weather conditions with taking into account resistance of the mining ship and lowered winning pipe. The value directly depends on :

hydro-meteorological parameters in zone of operation, i.e.: the average wind velocity $\mathrm{V}_{\mathrm{A}}$, average sea current velocity $\mathrm{V}_{\mathrm{C}}$ (both surface and deep-water one), significant wave height $\mathrm{H}_{\mathrm{S}}$

$>$ main parameters of the ship, its dimensions and its surface areas (above- and under-water) first of all

$>$ technical parameters of TW system (outer diameter of the pipe, $\mathrm{Dr}_{\mathrm{z}}$, its length $\mathrm{1}_{\mathrm{r}}$ )

$>$ assumed ship motion speed and accuracy of keeping its position and course.

As information on already designed and built mining ships are still lacking a preliminary design of such ship was used [1] to estimate demanded power for the SMC system in question. On this basis was selected one of the ship's versions characterized by its main dimensions, parameters, areas etc.

\section{POWER COMPONENTS OF SMC SYSTEM FOR SEA MINING SHIP FITTED WITH TW SYSTEM}

The total power of SMC system for mining ship, $\mathrm{N}_{\mathrm{SS}}$, is composed as follows:

$$
\mathrm{N}_{\mathrm{SS}}=\mathrm{N}_{\mathrm{B}}+\mathrm{N}_{\mathrm{R}}+\mathrm{N}_{\mathrm{S}}
$$

where:

$\mathrm{N}_{\mathrm{B}}$ - power necessary for generating the thrust of propellers to balance sea environment action [kW]

$\mathrm{N}_{\mathrm{R}}$ - power necessary for towing the TW system $\mathrm{N}_{\mathrm{R}}[\mathrm{kW}]$

$\mathrm{N}_{\mathrm{S}}$ - power necessary for generating the thrust of propellers to balance ship hull resistance to motion [kW].

In Fig. 2 the overall schematic diagram is presented of the estimation procedure of SMC system power in the preliminary phase of mining ship design.

\section{SEA ENVIRONMENT ACTION TO MINING SHIP}

Sea mining ship is more exposed to detrimental action of sea environment than transport ships because it is intended for many-year service at open sea. Hence the greatest disturbances during its motion control will result from :

$\star$ wind action

$\star$ sea wave action

$\star$ sea current action (surface and deep-water)

$\star$ resistance of ship hull and TW system (resulting from speed of ship and sea current).

Along with design practice, in determining maximum values of thrust and power of SMC system the most unfavourable action of sea environment to the ship is assumed. To this end it was assumed that wind and waves are directed perpendicularly to ship's plane of symmetry, i.e. $\beta_{\mathrm{Ay}}=\beta_{\mathrm{Wy}}=90^{\circ}$ and sea current - in opposite direction to ship motion, i.e. $\beta c_{x}=180^{\circ}$ (Fig. 3).

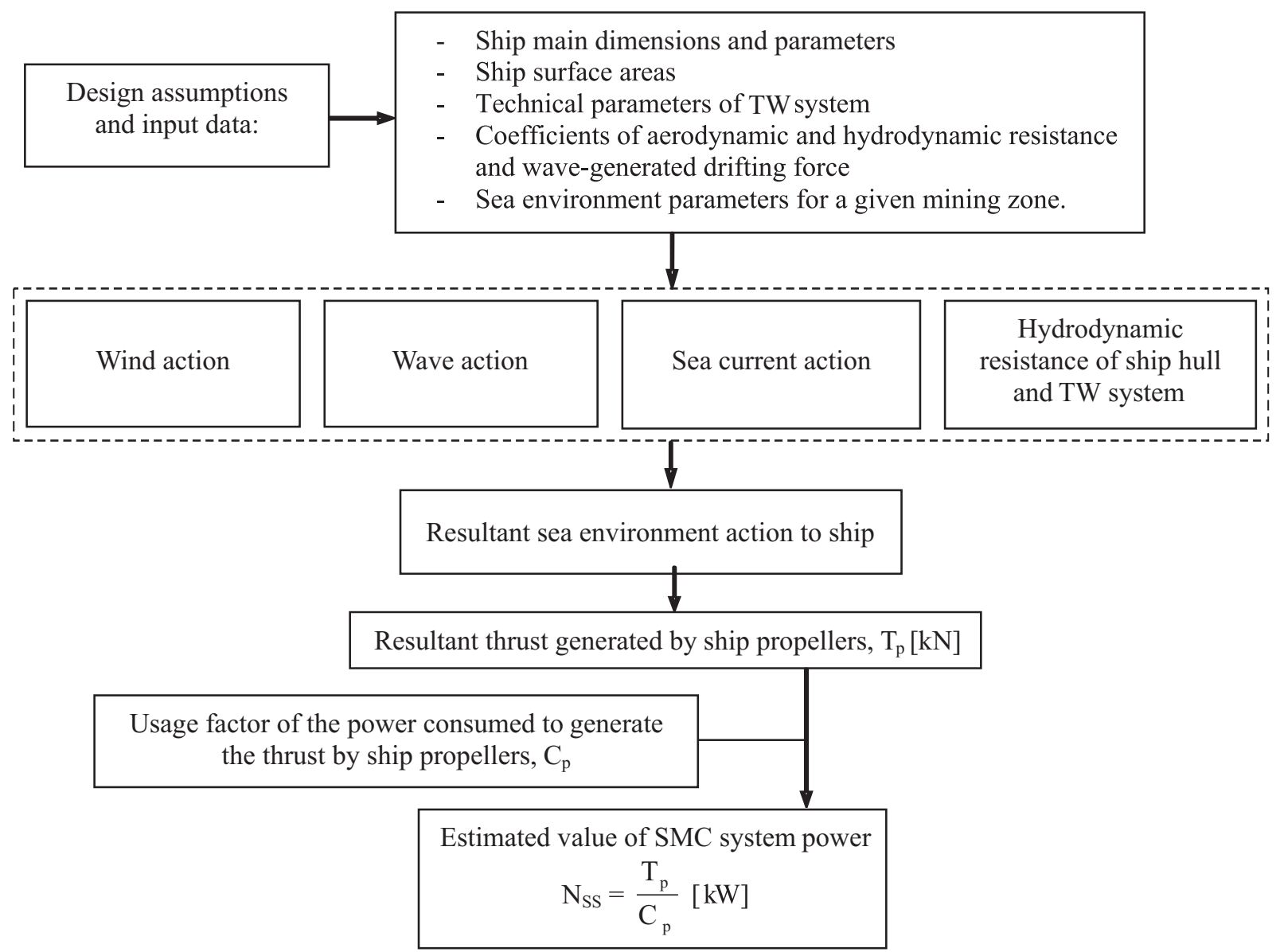

Fig. 2. Overall schematic diagram for estimation of SMC system power 


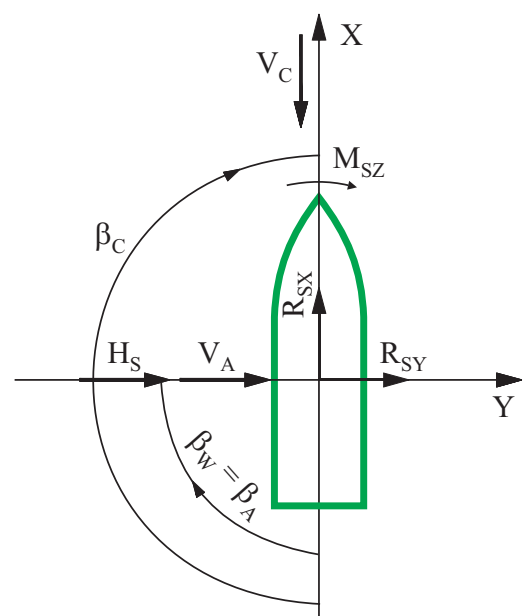

Fig. 3. Directions of sea environment action to ship

\section{WIND ACTION TO MINING SHIP}

In designing the SMC system the wind action is calculated for its average velocity and assumed direction with respect to the ship. Under the assumption that the wind is directed perpendicularly to the ship's plane of symmetry, i.e. $\beta_{\mathrm{A}}=90^{\circ}$ the average wind action was calculated by using the following formula :

$$
\mathrm{R}_{\mathrm{Ay}}=\frac{1}{2} \rho_{\mathrm{A}} \mathrm{S}_{\mathrm{y}} \mathrm{V}_{\mathrm{RA}}^{2} \mathrm{C}_{\mathrm{Ay}}\left(\beta_{\mathrm{RA}}\right)
$$

where:

$\mathrm{V}_{\mathrm{RA}}-$ average wind velocity $[\mathrm{m} / \mathrm{s}]$, (Fig. 4)

$\mathrm{S}_{\mathrm{y}}$ - windage lateral area [projected to ship's plane of

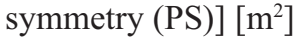

$\beta_{R A}-$ wind direction angle with respect to ship [ $\left.{ }^{\circ}\right]$, (Fig. 4)

$\mathrm{C}_{\mathrm{Ay}}-$ aerodynamic resistance coefficient of above-water body of ship.

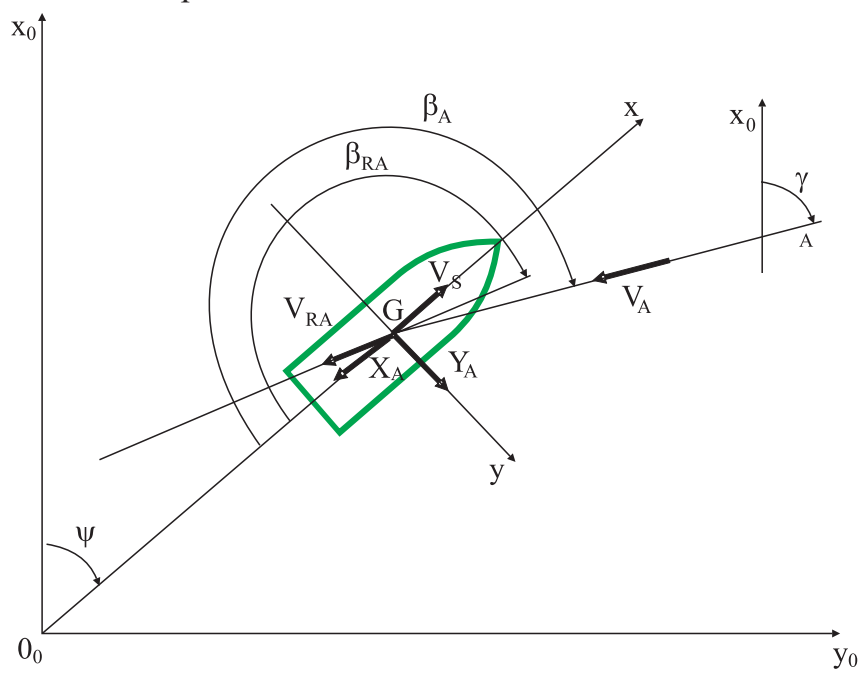

Fig. 4. Coordinate frame, velocities and directions of ship and wind

The relative wind velocity which appears in Eq. (1), is the average vectorial sum of the average absolute wind velocity and the velocity opposite to ship speed. The relative wind velocity can be calculated by means of the following formulae:

$$
\begin{aligned}
V_{\text {RA }} & =\sqrt{V_{R A x}^{2}+V_{\text {RAy }}^{2}} \\
V_{\text {RAx }} & =-V_{A} \cos \beta_{A}-V_{s} \\
V_{\text {RAy }} & =-V_{A} \sin \beta_{A}
\end{aligned}
$$

$$
\beta_{\mathrm{RA}}=\operatorname{arctg} \frac{\mathrm{V}_{\mathrm{RAy}}}{\mathrm{V}_{\mathrm{RAx}}}
$$

where:

$$
\mathrm{V}_{\mathrm{A}} \text { - average real wind velocity }[\mathrm{m} / \mathrm{s}]
$$

The wind action to moving ship can be calculated if the wind parameters $\left(\mathrm{V}_{\mathrm{A}}\right)$ aerodynamic resistance coefficients $\mathrm{C}_{\mathrm{Ay}}$ [5] (obtained from a ship of similar dimensions or model tests) for a given velocity $\mathrm{V}_{\mathrm{S}}$ and ship course angle $\psi$, are known.

As the mining ship will move at very low speeds it was assumed that the relative wind velocity and direction is equal to the absolute wind velocity and direction.

\section{SEA WAVE ACTION TO MINING SHIP}

In the determining of power demand for SMC system propellers, second-order actions which are non-linear and depend on square of wave ordinate, are taken into account. The wave-generated, second-order forces are also called wavegenerated drifting forces.

The average irregular-wave action to moving ship, at $\beta_{\mathrm{wy}}=90^{\circ}$, were calculated by means of the following formula:

$$
\mathrm{R}_{\mathrm{Wy}}=2 \rho_{\mathrm{w}} \mathrm{g} \frac{\mathrm{B}^{2}}{\mathrm{~L}} \int_{0}^{\infty} \mathrm{C}_{\mathrm{Wy}}\left(\omega / \beta_{\mathrm{w}}, \mathrm{V}\right) \mathrm{S}_{\zeta \zeta}(\omega) \mathrm{d} \omega
$$

where:

B, L - ship breadth and length [m], respectively

$\mathrm{C}_{\mathrm{Wy}}-$ coefficient of regular -wave -generated drifting force, dependent on the wave direction angle with respect to ship, $\beta_{\mathrm{w}}$, and ship's speed $\mathrm{V}_{\mathrm{s}}$

$\omega \quad-$ regular wave frequency $\left[\mathrm{s}^{-1}\right]$

$\beta_{\mathrm{w}}-$ wave direction angle with respect to ship [0], (Fig. 5)

$\mathrm{S}_{\zeta \zeta}^{\mathrm{w}} \quad-$ irregular -wave spectrum density function dependent on the significant wave height $\mathrm{H}_{\mathrm{s}}$ and average wave period $\mathrm{T}_{1}\left[\mathrm{~m}^{2} \mathrm{~s}\right]$.

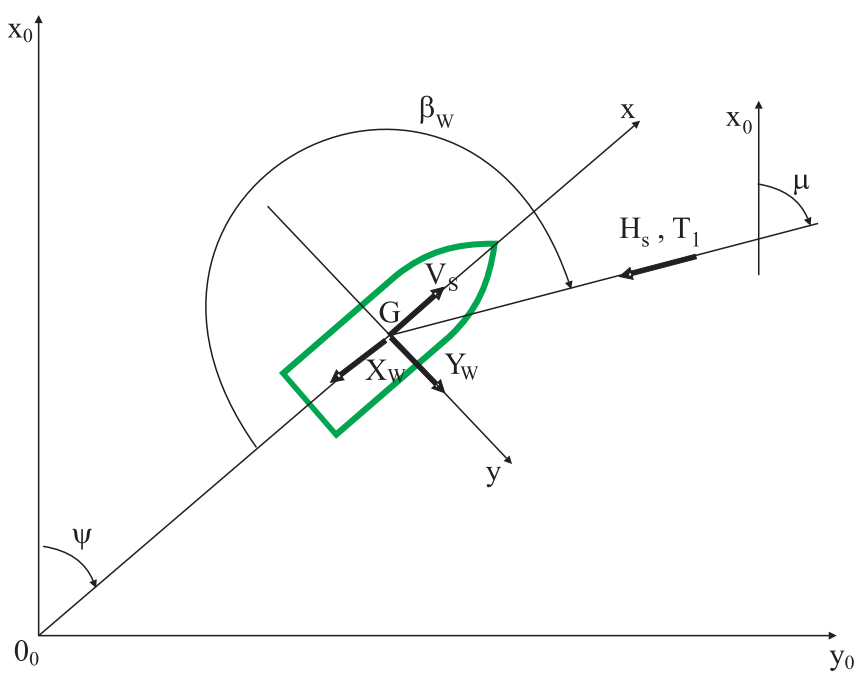

Fig. 5. Wave action to moving ship

For the calculations the ITTC standard function of wave energy spectrum density was assumed.

Assuming values of the wave parameters $\left(\mathrm{H}_{\mathrm{s}}, \mathrm{T}_{1}\right)$ and coefficients of wave-generated drifting force, $\mathrm{C}_{\mathrm{wy}}$, (determined from a ship of similar under-water body) for a given ship speed $\mathrm{V}_{\mathrm{S}}$ and course $\psi$, one can calculate the wave action to moving ship. 


\section{ACTION OF SEA SURFACE CURRENT AND WATER RESISTANCE TO MINING SHIP IN MOTION}

The average quasi-static action of sea surface current and water resistance to under-water body of mining ship at $\beta c_{x}=180^{\circ}$ was calculated by using the following formula:

$$
\mathrm{R}_{\mathrm{Cx}}=\frac{1}{2} \rho_{\mathrm{W}} \mathrm{F}_{\mathrm{x}} \mathrm{V}_{\mathrm{RV}}^{2} \mathrm{C}_{\mathrm{Cx}}\left(\beta_{\mathrm{RV}}\right)
$$

where:

$\mathrm{F}_{\mathrm{x}} \quad$ - head area of underwater portion of ship hull surface (projected to midship plane) $\left[\mathrm{m}^{2}\right]$

$\mathrm{V}_{\mathrm{RV}}$ - relative ship speed [m/s], (Fig. 6)

$\mathrm{C}_{\mathrm{Cx}}$ - hydrodynamic resistance coefficient of underwater body of ship, dependent on the angle $\beta_{\mathrm{RV}}$ (Fig. 6)

$\beta_{\mathrm{RV}}-$ relative ship's speed direction angle $\left[^{\circ}\right]$.

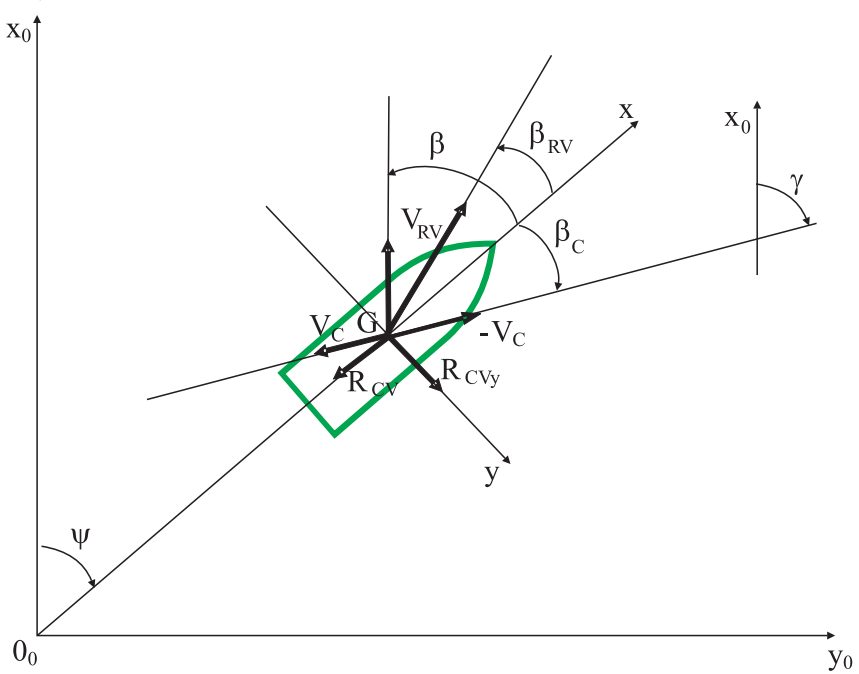

Fig. 6. Sea current and drifting ship directions

In calculations of the relative ship speed $\mathrm{V}_{\mathrm{RV}}$ and the direction angle $\beta_{\mathrm{RV}}$ the sea surface current velocity $\mathrm{V}_{\mathrm{C}}$ and its direction angle $\beta_{\mathrm{C}}$ should be taken into account.

The relative ship speed can be calculated according to the following formulae:

$$
\begin{gathered}
\mathrm{V}_{\mathrm{RV}}=\sqrt{\left(\mathrm{V}_{\mathrm{RV}_{\mathrm{X}}}\right)^{2}+\left(\mathrm{V}_{\mathrm{RV}_{\mathrm{Y}}}\right)^{2}} \\
\mathrm{~V}_{\mathrm{RVx}}=\mathrm{V}_{\mathrm{x}}-\mathrm{V}_{\mathrm{C}} \cos \beta_{\mathrm{C}} \\
\mathrm{V}_{\mathrm{RVy}}=\mathrm{V}_{\mathrm{y}}+\mathrm{V}_{\mathrm{C}} \sin \beta \\
\beta_{\mathrm{RV}}=\operatorname{arctg} \frac{\mathrm{V}_{\mathrm{RV}_{\mathrm{Y}}}}{\mathrm{V}_{\mathrm{RV}}}
\end{gathered}
$$

where:

$$
\begin{gathered}
\mathrm{V}_{\mathrm{x}}=\mathrm{V} \cos \beta, \mathrm{V}_{\mathrm{y}}=\mathrm{V} \sin \beta-\operatorname{ship} \text { speed components } \\
\beta-\text { ship drift angle }\left[^{\circ}\right] \text {, (Fig. 6) } \\
\mathrm{V}_{\mathrm{C}}-\text { sea surface current velocity [m/s], (Fig. 6). }
\end{gathered}
$$

\section{WATER RESISTANCE AND DEEP - WATER CURRENT ACTION TO TW SYSTEM}

TW system resistance depends on speeds of its motion and deep-water sea currents which continuously flow in determined directions, with determined velocities and at determined water depths. Hence the currents can act to the TW system pipe hung in water at various depths, in various, even opposite, directions.
The deep-water current velocity, ship speed and hydrodynamic resistance coefficients constitute the crucial factors affecting the TW system resistance to motion.

Such factors as weight of the pipes of which the TW system is composed, interaction of concretions floating through the system, or local deformations and vertical deflections of the TW installation are neglected since from the research on dynamic behaviour of TW system [6] it results that in the calculation phase in question they have no influence on the preliminary estimation of power demand for SMC system.

The average action of water and deep-water current to TW system was calculated by using the following equation:

$$
\mathrm{R}_{\mathrm{R}}=\frac{1}{2} \rho_{\mathrm{w}} \mathrm{Dr}_{\mathrm{z}} 1_{\mathrm{r}} \mathrm{V}_{\mathrm{RVg}}^{2} \mathrm{C}_{\mathrm{D}}\left(\mathrm{R}_{\mathrm{e}}\right)
$$

where:

$\mathrm{Dr}_{\mathrm{z}}-$ outer diameter of the pipe [m]

$1_{r}$ - length of the pipe $[\mathrm{m}]$

$\mathrm{C}_{\mathrm{D}}$ - hydrodynamic resistance coefficient dependent on the Reynolds number $\mathrm{R}_{\mathrm{e}}$.

Along with water depth changing the sea water physical parameters (such as dynamic viscosity, temperature, density) are also changing, and in consequence - the Reynolds number. Because of large discrepancies in research results on the changeability of the coefficient $C_{D}=f\left(R_{e}\right)$ and lack of its precise definition, the results of Achenbach's analyses [2] were taken into consideration.

The velocity field of deep-water currents, combined with the motion speed of TW system, yields the relative water velocity $\mathrm{V}_{\mathrm{RV}}$ :

$$
\begin{gathered}
\mathrm{V}_{\mathrm{RVg}}=\sqrt{\left(\mathrm{V}_{\mathrm{RV}}\right)^{2}+\left(\mathrm{V}_{\mathrm{RV}_{\mathrm{Y}}}\right)^{2}} \\
\mathrm{~V}_{\mathrm{RVx}}=\mathrm{V}_{\mathrm{x}}-\mathrm{V}_{\mathrm{g} \uparrow} \cos \beta_{\mathrm{g} \uparrow} \\
\mathrm{V}_{\mathrm{RVy}}=\mathrm{V}_{\mathrm{y}}+\mathrm{V}_{\mathrm{gt}} \sin \beta_{\mathrm{g} \uparrow} \\
\beta_{\mathrm{RV}}=\operatorname{arctg} \frac{\mathrm{V}_{\mathrm{RV}}}{\mathrm{V}_{\mathrm{RV}_{\mathrm{X}}}}
\end{gathered}
$$

where:

$\mathrm{V}_{\mathrm{g} t}-$ resultant velocity of deep-water current $[\mathrm{m} / \mathrm{s}]$, $\mathrm{V}_{\mathrm{RVg}}^{\mathrm{gt}}$ - relative water velocity [m/s].

\section{MAXIMUM RESULTANT ACTION OF SEA ENVIRONMENT TO MINING SHIP}

In compliance with designing practice, the most unfavourable direction of sea environment action to ship (Fig. 3) was assumed for calculation of power demand for the SMC system. Therefore in the calculations influence of the external moments $\mathrm{M}_{\mathrm{Az}}, \mathrm{M}_{\mathrm{Wz}}$, $\mathrm{M}_{\mathrm{Cz}}$, was neglected as values of the moments are minimum at the assumed angles $\beta_{\mathrm{A}}=\beta_{\mathrm{W}}=90^{\circ}$. They attain maximum values at an oblique action of wind and wave but in such case values of power demand for the SMC system propellers are smaller.

The maximum resultant action of sea environment to mining ship is due to wind, waves, sea currents and water resistance, and for the made assumptions (Fig. 3) it is a sum of particular components of axial and lateral actions :

$$
\begin{gathered}
\mathrm{R}_{\mathrm{Sx}}=\mathrm{R}_{\mathrm{Cx}}+\mathrm{R}_{\mathrm{Rx}} \\
\mathrm{R}_{\mathrm{Sy}}=\mathrm{R}_{\mathrm{Ay}}+\mathrm{R}_{\mathrm{Wy}}
\end{gathered}
$$


where:

$\mathrm{R}_{\text {Ay }}-$ component of wind action to above-water portion of mining ship's hull

$\mathrm{R}_{\mathrm{wy}}$ - component of wave-generated drifting force action to mining ship's hull

$\mathrm{R}_{\mathrm{Cx}}$ - component of resultant water-flow action to mining ship's hull, due to sea surface current and ship's speed

$\mathrm{R}_{\mathrm{Rx}}$ - component of water action to TW system (due to deepwater currents and the system's motion speed).

\section{THRUST AND POWER DEMAND FOR THE SMC SYSTEM}

Having the components of resultant sea environment action to the mining ship during keeping its position and course along a given trajectory, one is able to determine the components of resultant thrust generated by propellers of the SMC system, which balance the action. In the preliminary design phase it was assumed that for so large ships as mining ones and so large electric power demanded for them, the total resultant thrust, $\mathrm{T}_{\mathrm{S}}$, of the SMC system propellers is equal to :

$$
\begin{aligned}
& \mathrm{T}_{\mathrm{Sx}}=\mathrm{a}_{\mathrm{x}} * \mathrm{R}_{\mathrm{Sx}} \\
& \mathrm{T}_{\mathrm{Sy}}=\mathrm{a}_{\mathrm{y}} * \mathrm{R}_{\mathrm{Sy}}
\end{aligned}
$$

where:

$\mathrm{R}_{\mathrm{Sx}}, \mathrm{R}_{\mathrm{Sy}}-$ components of resultant action of sea environment $\mathrm{a}_{\mathrm{x}}, \mathrm{a}_{\mathrm{y}}-$ additional resultant thrust of propeller to balance inertia and damping forces resulting from slowchangeable motions of the ship.

Components of the resultant thrust generated by propellers of the SMC system are sums of thrusts generated by its particular propellers. Power delivered to every propeller of the system can be approximately determined from the following relationship :

$$
\mathrm{N}_{\mathrm{P}}=\frac{\mathrm{T}_{\mathrm{P}}}{\mathrm{C}_{\mathrm{P}}}
$$

where:

$\mathrm{T}_{\mathrm{P}}$ - thrust generated by every propeller of the SMC system [kN]

$\mathrm{C}_{\mathrm{P}}$ - usage factor of propeller power for generating the thrust.

Because of low speeds of the ship the power demanded for the propellers used in the SMC system will be calculated by applying the usage factor of propeller power for generating the thrust.

Propellers used in such systems are special ones; they are adjusted to operation at low speeds (even equal to zero), zero advance ratio and small values of wake fraction.

In the preliminary design phase when data on type, diameter, revolutions and pitch of ship propellers and on engine - propeller interaction are still unknown it is not possible to precisely estimate values of the factor $\mathrm{C}_{\mathrm{p}}$ in function of ship speed. As it results from performed preliminary analyses, influence of ship speed on $\mathrm{C}_{\mathrm{p}}$ factor value is negligibly small within the speed range of $0.257 \div 1.285 \mathrm{~m} / \mathrm{s}$, hence its average value was assumed irrespective of ship speed.

Power demand for SMC system during mining operations is equal to the total power demanded by all the propellers used to generate the thrust necessary to balance sea environment action:

$$
\mathrm{N}_{\mathrm{SS}}=\Sigma \mathrm{N}_{\mathrm{P}}[\mathrm{kW}]
$$

The total thrust of propellers, this way determined, corresponds with the conditions for selecting the power source characteristics, i.e. the satisfying of maximum design power demand.

\section{ESTIMATION OF THRUST AND POWER OF SMC SYSTEM PROPELLERS FOR PURPOSES OF PRELIMINARY DESIGN OF SEA MINING SHIP}

In the calculations was used the preliminary design concept

\begin{tabular}{|c|c|c|}
\hline & \multicolumn{2}{|l|}{ Main parameters of sea mining ship } \\
\hline \multirow{4}{*}{ 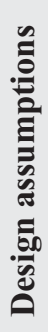 } & $\begin{array}{l}\text { Yearly mining rate of wet concretions } \\
{\left[10^{6} \mathrm{t} / \text { year }\right]}\end{array}$ & 1.750 .000 \\
\hline & $\begin{array}{l}\text { Period of storing the concretions in holds } \\
\text { [days] }\end{array}$ & 10 \\
\hline & Operational period [days/year] & 292 \\
\hline & Average density of concretions $\left[\mathrm{t} / \mathrm{m}^{3}\right]$ & 2 \\
\hline \multirow{11}{*}{ 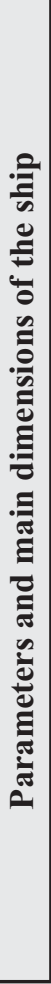 } & Length b.p. $\mathrm{L}_{\mathrm{pp}}[\mathrm{m}]$ & 215.6 \\
\hline & Breadth B [m] & 40.68 \\
\hline & Hull depth $\mathrm{H}[\mathrm{m}]$ & 19.37 \\
\hline & Draught $\mathrm{T}[\mathrm{m}]$ & 12.83 \\
\hline & Hull block coefficient $\mathrm{C}_{\mathrm{B}}[-]$ & 0.83 \\
\hline & Displacement $\Delta[\mathrm{t}]$ & 96250 \\
\hline & Deadweight $\mathrm{P}_{\mathrm{N}}[\mathrm{t}]$ & 75469 \\
\hline & Load capacity $[\mathrm{t}]$ & 61130 \\
\hline & Windage lateral area of ship, $\mathrm{S}_{\mathrm{y}}\left[\mathrm{m}^{2}\right]$ & 3850 \\
\hline & $\begin{array}{l}\text { Lateral area of under-water surface of ship, } \\
\qquad F_{y}\left[\mathrm{~m}^{2}\right]\end{array}$ & 2980 \\
\hline & $\begin{array}{l}\text { Head area of under-water surface of ship, } \\
\qquad \mathrm{F}_{\mathrm{x}}\left[\mathrm{m}^{2}\right]\end{array}$ & 512 \\
\hline
\end{tabular}
of the sea mining ship whose main parameters are given in Tab. 1.

Tab. 1. Values of main parameters of sea mining ship acc. [1]

To calculate at first sea environment action to the mining ship fitted with TW system and then trust and power of SMC system, the formulae $(1) \div(13)$ and the following assumptions were used:

the design weather conditions in the assumed zone of mining operations, in three variants :

- Variant 1: $\mathrm{V}_{\mathrm{A}}=18 \mathrm{~m} / \mathrm{s} ; \mathrm{H}_{\mathrm{S}}=5 \mathrm{~m} ; \mathrm{V}_{\mathrm{C}}=1.1 \mathrm{~m} / \mathrm{s}$; $\mathrm{V}_{\mathrm{gt}}=0.55 \mathrm{~m} / \mathrm{s}$

- Variant 2: $\mathrm{V}_{\mathrm{A}}=22 \mathrm{~m} / \mathrm{s} ; \mathrm{H}_{\mathrm{S}}=6 \mathrm{~m} ; \mathrm{V}_{\mathrm{C}}=1.1 \mathrm{~m} / \mathrm{s}$; $\mathrm{V}_{\mathrm{gf}}=0.55 \mathrm{~m} / \mathrm{s}$,

- Variant $3: \mathrm{V}_{\mathrm{A}}=26 \mathrm{~m} / \mathrm{s} ; \mathrm{H}_{\mathrm{s}}=7 \mathrm{~m} ; \mathrm{V}_{\mathrm{C}}=1.1 \mathrm{~m} / \mathrm{s}$; $\mathrm{V}_{\mathrm{gt}}=0.55 \mathrm{~m} / \mathrm{s}$, 
$\rightarrow$ the mining ship speed range $: \mathrm{V}_{\mathrm{s}}=0.5 \div 2.5 \mathrm{kn}$

$\rightarrow$ the TW system technical parameters : $\mathrm{Dr}_{\mathrm{z}}=0.28 \mathrm{~m}$, $1_{\mathrm{r}}=4600 \mathrm{~m}$ acc. [2]

O ship's main parameters and surface areas acc. [1]

$\rightarrow$ values of the coefficients : $\mathrm{C}_{\mathrm{Ay}}=0.96$ and $\mathrm{C}_{\mathrm{xC}}=0.85$ acc. [5].

The range of design sea environmental conditions results from some optimization analyses (which was not a subject of this research).

Maximum sea environmental conditions in which the mining ship is intended to operate are assumed on such level as to obtain a rational value of operational costs and an optimum form of the whole process. Hence for the calculations only a certain range of design sea environmental conditions was assumed by using the results of the research on influence of weather conditions on design criteria [9].

\section{RESULTS OF THE CALCULATIONS}

\section{Sea environment action to sea mining ship}

In Tab. 2 are presented the calculation results of the wind action $\mathrm{R}_{\mathrm{Ay}}$, that of wave, $\mathrm{R}_{\mathrm{Wy}}$ and of surface current, $\mathrm{R}_{\mathrm{Cx}}$, to sea mining ship for different sea environmental conditions.

Tab. 2. The calculation results of the wind, wave and surface current actions to sea mining ship

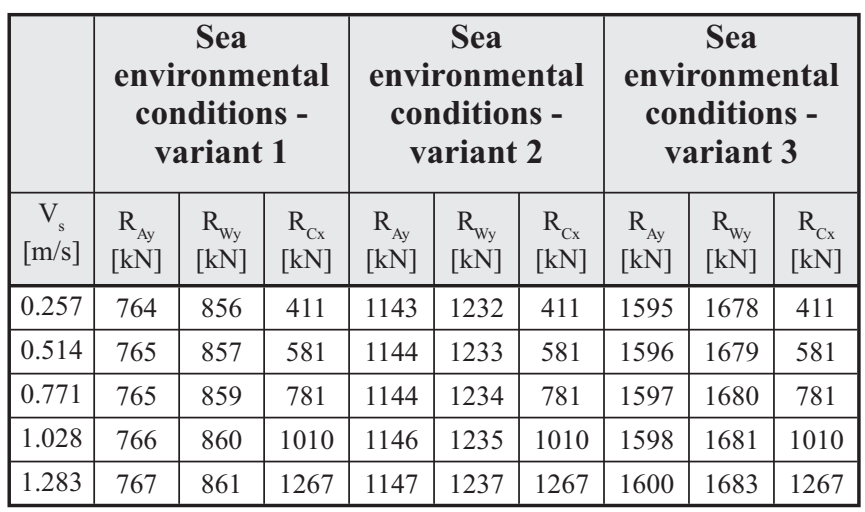

The calculation results of the hydrodynamic resistance of TW system, $R_{R}$, and ship hull resistance to motion, $R_{T}$, in function of ship speed are given in Tab. 3 .

Tab. 3. Ship hull resistance to motion

and TW system resistance to motion and deep-water currents

\begin{tabular}{|c|c|c|}
\hline $\begin{array}{c}\text { Ship speed } \\
\mathbf{V}_{\mathbf{S}}[\mathbf{m} / \mathbf{s}]\end{array}$ & $\begin{array}{c}\text { Hull resistance } \\
\mathbf{R}_{\mathbf{T}}[\mathbf{k N}]\end{array}$ & $\begin{array}{c}\text { TWS resistance } \\
\mathbf{R}_{\mathbf{r}}[\mathbf{k N}]\end{array}$ \\
\hline 0.257 & 4.0 & 515 \\
\hline 0.514 & 13.0 & 917 \\
\hline 0.771 & 28.0 & 1446 \\
\hline 1.028 & 48.0 & 2107 \\
\hline 1.283 & 73.0 & 2892 \\
\hline
\end{tabular}

Values of the total resistance of mining ship hull, $\mathrm{R}_{\mathrm{T}}$, for the assumed and controlled speed values during mining operations, were calculated by means of the Holtrop - Mennen method.

\section{Thrust and power output of the SMC system propellers}

The calculation results of thrust of ship propellers and main components of power of SMC system are presented in function of ship speed in Tab. 4 and Fig. 7.
Tab. 4. Values of thrust of ship propellers and main components of power of SMC system

\begin{tabular}{|c|c|c|c|c|c|c|c|c|}
\hline \multirow[t]{2}{*}{$\begin{array}{c}\text { Ship } \\
\text { speed }\end{array}$} & \multicolumn{3}{|c|}{$\begin{array}{l}\text { Thrust components } \\
{[\text { [kN] }}\end{array}$} & \multirow[t]{2}{*}{$\begin{array}{l}\text { Thrust } \\
\mathrm{T}[\mathrm{kN}]\end{array}$} & \multicolumn{3}{|c|}{$\begin{array}{l}\text { Power components } \\
\qquad[\mathrm{kW}]\end{array}$} & \multirow{2}{*}{$\begin{array}{c}\text { Power } \\
\mathbf{N}_{\mathrm{ss}} \\
{[\mathbf{k W}]}\end{array}$} \\
\hline & $\mathbf{T}_{\mathbf{B}}{ }^{\left({ }^{*}\right)}$ & $T_{R}$ & $\mathbf{T}_{\mathrm{s}}$ & & $\mathbf{N}_{\mathbf{B}}{ }^{(*)}$ & $\mathbf{N}_{\mathrm{R}}$ & $\mathbf{N}_{\mathrm{s}}$ & \\
\hline 0.257 & 3868 & 541 & 4.0 & 4413 & 19341 & 2705 & 5.0 & 22051 \\
\hline 0.514 & 4049 & 963 & 14.0 & 5026 & 20244 & 4814 & 35.0 & 25130 \\
\hline 0.771 & 4261 & 1519 & 29.0 & 5809 & 21305 & 7593 & 113.0 & 29045 \\
\hline 1.028 & 4504 & 2212 & 50.0 & 6766 & 22517 & 11062 & 259.0 & 33830 \\
\hline 1.283 & 4778 & 3037 & 77.0 & 7892 & 23888 & 15185 & 492.0 & 39460 \\
\hline
\end{tabular}

${ }^{(*)}$ Thrust and power calculated for the sea environmental conditions - variant 3

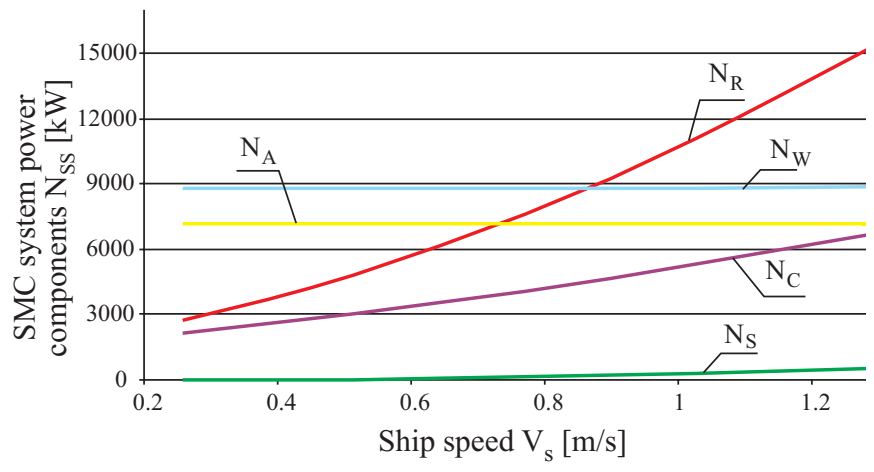

Fig. 7. The SMC system's power components : $N_{A}, N_{W} N_{C}, N_{S}, N_{R}$

\section{CONCLUSIONS}

In this paper is presented an analysis of estimation of maximum design power of a ship motion control (SMC) system intended for the preliminarily designed ship for mining Fe-Mn concretions, described in [1].

The factors crucial for the generating of motion disturbances of the ship fitted with tubular winning (TW) system during its movement along a given trajectory within a corridor, i.e. action of wind, wave, sea currents (surface and deep-water), resistance of ship hull and TW system, have been specified.

On the basis of the performed analytical calculations it can be stated that the largest share in the power necessary for the SMC system is attributed to that for towing the TW system. The towing power (Fig. 7) increases dynamically along with ship speed and reaches large values. Hence one of the main operational problems will be to provide such large values of the power $\mathrm{N}_{\mathrm{R}}$ as well as to find an appropriate technical solution for towing the deeply immersed pipe.

And, the smallest share is associated with the power necessary to generate propellers' thrust to overcome ship hull resistance to motion; it results from very low values of the ship's speed. Hence it can be assumed negligible.

Due to its power demand the SMC system will constitute one of the largest power consumers out of those installed in the whole power system. Taking into consideration that the percentage share of the system's power in the total power balance amounts to about $60 \div 80 \%$ one can suppose that the total output of the electric power plant installed onboard the mining ship will be of the order of a few dozen megawatts. 


\section{NOMENCLATURE}

$\mathrm{a}_{\mathrm{x}, \mathrm{y}} \mathrm{a}_{\mathrm{y}} \quad-$ additional resultant propeller thrust to balance inertia and damping forces resulting from slow-changeable motions of the ship

B $\quad-$ ship breadth [m]

$\mathrm{C}_{\mathrm{Ay}} \quad-$ aerodynamic resistance coefficient [-]

$\mathrm{C}_{\mathrm{B}}^{\mathrm{Ay}} \quad-$ hull block coefficient [-]

$\mathrm{C}_{\mathrm{cx}} \quad-$ hydrodynamic resistance coefficient of under-water portion of ship hull [-]

$\mathrm{C}_{\mathrm{D}} \quad-$ hydrodynamic resistance coefficient [-]

$\mathrm{C}_{\mathrm{p}} \quad-$ usage factor of the power consumed to generate thrust by ship propellers

$\mathrm{C}_{\mathrm{Wy}}-$ coefficient of drifting force generated by regular wave $[-]$

$\operatorname{Dr}_{z} \quad-$ outer diameter of wining system's pipe [m]

$\mathrm{F}_{\mathrm{x}}, \mathrm{F}_{\mathrm{y}} \quad$ - areas of under-water hull surface projected to midship plane and ship plane of symmetry, respectively $\left[\mathrm{m}^{2}\right]$

g $\quad-$ earth gravity acceleration $\left[\mathrm{m} / \mathrm{s}^{2}\right]$

$\mathrm{H} \quad-$ ship hull depth [m]

$\mathrm{H}_{\mathrm{s}} \quad-$ significant wave height $[\mathrm{m}]$

$1_{\mathrm{s}}^{\mathrm{S}} \quad-$ length of the pipe

$l_{y}^{r} \quad-$ length of winning system's pipe $[\mathrm{m}]$

$\mathrm{L}_{\mathrm{pp}}^{\mathrm{y}} \quad$ - ship length between perpendiculars [m]

$\mathrm{N}_{\mathrm{A}}^{\mathrm{pp}} \quad-$ power for generating the thrust necessary to balance wind action $[\mathrm{kW}]$

$\mathrm{N}_{\mathrm{B}} \quad-$ power for generating the thrust necessary to balance sea environmental action (wind + wave + current) $[\mathrm{kW}]$

$\mathrm{N}_{\mathrm{C}} \quad-$ power for generating the thrust necessary to balance sea current action $[\mathrm{kW}]$

$\mathrm{N}_{\mathrm{p}} \quad-$ power $[\mathrm{kW}]$

$\mathrm{N}_{\mathrm{R}}^{\mathrm{P}} \quad-$ power for towing the winning system pipe $[\mathrm{kW}]$

$\mathrm{N}_{\mathrm{S}}^{\mathrm{R}} \quad-$ power for generating the thrust necessary to balance hull resistance to motion $[\mathrm{kW}]$

$\mathrm{N}_{\mathrm{SS}} \quad-$ total power of ship motion control system [kW]

$\mathrm{N}_{\mathrm{W}} \quad-$ power for generating the thrust necessary to balance wave-generated drifting force $[\mathrm{kW}]$

$\mathrm{P}_{\mathrm{N}} \quad-\quad$ ship deadweight [t]

$\mathrm{R}_{\mathrm{Ay}}^{\mathrm{N}} \quad-$ component of wind action to above-water portion of mining ship hull $[\mathrm{kN}]$

$\mathrm{R}_{\mathrm{Rx}} \quad-$ component of water action to tubular winning system $[\mathrm{kN}]$

$\mathrm{R}_{\mathrm{wy}} \quad$ - component of wave-generated drifting force action to mining ship hull $[\mathrm{kN}]$

$\mathrm{R}_{\mathrm{Cx}} \quad$ - component of resultant water - flow action to ship hull, due to sea surface current and ship speed $[\mathrm{kN}]$

$\mathrm{R}_{\mathrm{R}} \quad$ - resistance of tubular winning system to motion $[\mathrm{kN}]$

$\mathrm{R}_{\mathrm{T}}^{\mathrm{R}} \quad-$ total resistance of ship hull [kN]

$\mathrm{S}_{\mathrm{x}}, \mathrm{S}_{\mathrm{y}} \quad$ - windage areas projected to midship plane and plane of symmetry, respectively $\left[\mathrm{m}^{2}\right]$

$\mathrm{S}_{\zeta \zeta}(\omega) \quad-$ wave energy spectrum density $\left[\mathrm{m}^{2} \mathrm{~s}\right]$

$\mathrm{T}^{\zeta \zeta} \quad-$ ship draught $[\mathrm{m}]$

$\mathrm{T}_{\mathrm{p}} \quad-$ thrust of propellers of ship motion control system [kN]

$\mathrm{T}_{\mathrm{Sx}}^{\mathrm{p}}, \mathrm{T}_{\mathrm{Sy}}-$ components of resultant thrust of propellers of ship motion control system, necessary to balance sea environment action to ship, $[\mathrm{kN}]$

$\mathrm{V}_{\mathrm{S}} \quad-$ ship speed $[\mathrm{m} / \mathrm{s}]$

$\mathrm{V}_{\mathrm{A}} \quad-$ average wind velocity $[\mathrm{m} / \mathrm{s}]$

$\mathrm{V}_{\mathrm{C}} \quad-$ sea surface current velocity $[\mathrm{m} / \mathrm{s}]$

$\mathrm{V}_{\mathrm{of}} \quad-$ resultant velocity of deep-water current $[\mathrm{m} / \mathrm{s}]$

$\mathrm{V}_{\mathrm{RA}}^{\mathrm{gf}} \quad-$ relative wind velocity $[\mathrm{m} / \mathrm{s}]$

$\mathrm{V}_{\mathrm{RV}}^{\mathrm{RA}} \quad-$ relative current velocity $[\mathrm{m} / \mathrm{s}]$

$\mathrm{V}_{\mathrm{RVg}}^{\mathrm{RV}} \quad-$ relative water-flow velocity $[\mathrm{m} / \mathrm{s}]$
$\mathrm{V}_{\mathrm{RV}}, \mathrm{V}_{\mathrm{RV}}-$ components of relative water-flow velocity [m/s]

$\beta^{\mathrm{RVX}},{ }^{\mathrm{RVy}}-$ ship drift angle $\left[{ }^{\circ}\right]$

$\beta_{\mathrm{A}}-$ wind direction angle with respect to ship $\left[{ }^{\circ}\right]$

$\beta_{\mathrm{C}}-$ sea current direction angle with respect to ship [ $\left.{ }^{\circ}\right]$

$\beta_{\mathrm{RA}}-$ relative wind direction angle $\left[{ }^{\circ}\right]$

$\beta_{\mathrm{RC}}-$ relative current direction angle $\left[{ }^{\circ}\right]$

$\beta_{\mathrm{RV}}-$ relative drift angle $\left[{ }^{\circ}\right]$

$\beta_{\mathrm{W}}-$ wave direction angle with respect to ship $\left[{ }^{\circ}\right]$

$\rho_{\mathrm{A}} \quad-$ air density $\left[\mathrm{t} / \mathrm{m}^{3}\right]$

$\rho_{\mathrm{w}} \quad-$ sea water density $\left[\mathrm{t} / \mathrm{m}^{3}\right]$

$\Delta \quad-$ ship displacement $[\mathrm{t}]$

$\omega \quad-\quad$ frequency of harmonic wave component (linear regular wave) $\left[\mathrm{s}^{-1}\right]$.

\section{BIBLIOGRAPHY}

1. Bortnowska M.: A method of estimation of power demand for motion control system of floating unit during operation of mining $\mathrm{Fe}-\mathrm{Mn}$ concretions, applicable in preliminary designing (in Polish). Doctor's thesis, Szczecin University of Technology, 2006

2. Cheng B., Chung J.S.: Application of Thrusts to Elastic Joints on Long Vertical Pipe in 3-D Nonlinear Motions - Part II: Numerical Examples by MSE an FEM Results, International Offshore and Polar Engineering Conference Montreal, Canada, May 24-29, 1998

3. Hogben N., Lumb F. E.: Ocean Wave Statistics, National Physical Laboratory, London 1967

4. Неизвнесимстнов Я. В., Глумов И. Ф.: Инженерная геология рудной провиниии Кларион-Клиппертон в тихом океане, Труды, Том 197, Наука, Санкт-Петерсбург, 2004

5. A group of authors, Brix J. Ed.: Manoeuvring Technical Manual. Hamburg, 1993

6. Szelangiewicz T.: Research on dynamic behaviour of a winning facility for mining the concretions from seabed (in Polish). Research report 5T12C 012 25, Faculty of Maritime Technology, Szczecin University of Technology, Szczecin 2006

7. Sobota J.: Estimation of power demand for winning the concretions from seabed (in Polish). Interoceanmetal Common Enterprise, Szczecin 2003

8. Szelangiewicz T.: Research on influence of displacement and main dimensions of a base ship for underwater operations on power of ship's dynamic positioning system (in Polish), Proceedings of $4^{\text {th }}$ Conference on Design and Construction of Ocean Engineering Objects, Ocean Engineering Committee, Scientific Technical Session, SIMP Shipbuilding Section, Szczecin 1987

9. Szelangiewicz T.: Influence of weather conditions on design criteria for ocean engineering units (in Polish). Proceedings of 8th International Symposium on Ship Hydromechanics, Wrocław 1989.

\section{CONTACT WITH THE AUTHOR}

Monika Bortnowska, Ph. D. Faculty of Marine Technology, Szczecin University of Technology Al. Piastów 41

71-065 Szczecin, POLAND e-mail : mwojciechowska@ps.pl tel.: (091) 4494720 